\title{
USING HUMAN RightS TREATIES TO RESOLVE AMBIGUITY: THE ADVENT OF A RigHTS-CONSCIOUS CHARMING BETSY CANON
}

\author{
Melissa A Waters*
}

This article considers the role of international human rights law in the domestic context, and examines in particular the use of what the author calls a "rights-conscious Charming Betsy canon", whereby judges in New Zealand, Canada, the United States and Australia have interpreted statutory provisions (focusing on the case study of immigration law) so as to be consistent with international human rights norms. The author also considers the more radical use of the canon, proposed in particular by the High Court of Australia's Justice Kirby, which proposes that even constitutional texts may be interpreted to be consistent with international law, and discusses the threat this poses to traditional common law dualism.

One of the most significant developments in international law over the past decade has been the emergence of a rich transnational judicial dialogue among the world's common law courts. While transnational judicial dialogue is emerging across a wide range of substantive law areas, thus far the scholarly debate over dialogue has focused largely on the use of international human rights law in interpreting domestic constitutional texts. Equally significant forms of dialogue are taking place outside the constitutional context, however, and thus far these other forms have received far less scholarly attention.

One particularly overlooked arena for transnational judicial dialogue on human rights is in the interpretation of statutory law. Courts have long looked to international law to interpret statutes. In the United States, for example, the so-called Charming Betsy canon of statutory interpretation holds that "an act of Congress ought never to be construed to violate the law of nations, if any other possible construction remains." ${ }^{1}$ United States courts have applied the Charming Betsy canon to construe ambiguous statutes in such a manner that they would not violate either international treaties

* Assistant Professor of Law, Washington \& Lee Law School.

1 Murray v Schooner Charming Betsy (1804) 6 US 64, 118 Marshall J. 
or customary international law. ${ }^{2}$ Other courts from the common law tradition have long had their own approaches analogous to the Charming Betsy canon.

Over the past decade, common law courts have begun to transform the centuries-old Charming Betsy canon into an extraordinarily powerful judicial tool for entrenching international human rights obligations into domestic law. By developing what I will refer to as a "rights-conscious Charming Betsy canon", courts are able to utilise treaties to interpret domestic statutes consistently with international legal human rights norms. In addition, some judges have urged for the expansion of the rights-conscious approach beyond the statutory context, arguing that courts should adopt the Charming Betsy canon to interpret ambiguities in constitutional texts. In both contexts, transnational judicial dialogue has played a key role in encouraging the development of a rightsconscious approach. Human rights treaties have become a kind of bridging device: courts use them as common reference points around which to construct a dialogue with their foreign counterparts regarding both the content of human rights law and the proper application of that law to interpret domestic legal texts.

As we shall see, the emergence of the rights-conscious Charming Betsy canon has reinvigorated the debate over the proper role for treaties in common law legal systems. Traditional common law dualism holds that a treaty has domestic legal effect in only two situations: first, if it has been incorporated by legislation, or second, if courts are utilising the treaty as evidence of the existence of a customary international law norm. The traditional Charming Betsy canon fits well within the dualist paradigm, because it emphasises respect for the political branches, particularly the legislature. As Professor Ralph Steinhardt has observed, by seeking to read domestic legislation consistently with international commitments undertaken by the political branches, Charming Betsy "assures that [a country] is not compromised or embarrassed in its foreign relations." 3 From a dualist standpoint, the traditional Charming Betsy canon is "a restrictive and prophylactic doctrine protecting the separation of powers." 4

The emerging rights-conscious Charming Betsy canon, however, is considerably more monist in orientation than its historical predecessor. It emphasises respect for international law rather than judicial deference to political branch prerogatives in treaty incorporation. Courts employing the canon utilise unincorporated human rights treaties to inform the substantive content of domestic statutes. In so doing, they are developing a flexible, powerful and increasingly controversial judicial tool for entrenching human rights treaty obligations into domestic law. This essay explores the

2 See for example, TWA v Franklin Mint Corp (1984) 466 US 243, 252 O'Connor J ("There is, first, a firm and obviously sound canon of construction against finding implicit repeal of a treaty in ambiguous congressional action.").

3 Ralph G Steinhardt "The Role of International Law As a Canon of Domestic Statutory Construction" (1990) 43 Vand L Rev 1103, 1197.

4 Ibid, 1130. 
emergence of a rights-conscious Charming Betsy canon in both statutory and constitutional interpretation, and considers its implications for traditional common law dualism.

\section{I "RIGHTS-CONSCIOUS" STATUTORY INTERPRETATION: JUDICIAL SUPERVISION OF ADMINISTRATIVE DECISION-MAKING}

A key emerging arena for the development of the rights-conscious Charming Betsy canon is in statutory interpretation regarding administrative decision-making. A series of immigration cases from Australia, Canada, New Zealand and the United States are representative of this trend. In these cases, the courts utilise the Charming Betsy approach to incorporate international human rights obligations into their countries' immigration law. They do so by requiring administrative officials to exercise their statutory discretion in accordance with the terms of human rights treaties, despite the unincorporated status of those treaties within the domestic legal system. The cases reveal the significant role that transnational judicial dialogue is playing in the development of the rightsconscious Charming Betsy canon. At the same time, they reveal significant differences in technique and in judicial attitudes regarding the appropriate use of the rights-conscious approach.

\section{A New Zealand}

In Tavita v Minister of Immigration, ${ }^{5}$ the New Zealand Court of Appeal employed the rightsconscious approach in holding that immigration officials have an obligation to take human rights treaties into consideration in exercising discretion under the New Zealand Immigration Act. In a previous decision addressing the issue, Ashby $v$ Minister of Immigration, ${ }^{6}$ the court had held that judicial review of administrative decision-making in such cases was extremely limited. It explained that it was only when a statute "expressly or by implication identifies a consideration as one to which regard must be had that the Courts can interfere for failure to take it into account." 7 The Ashby court then described the "elementary" dualist proposition that "international treaty obligations are not binding in domestic law until they have become incorporated" by statute. ${ }^{8}$ Combining these two propositions, the Ashby court held that even in cases where immigration officials had failed to take New Zealand's international human rights obligations into account in exercising their statutory discretion, traditional dualist limitations prevented judicial review of their actions. ${ }^{9}$

Thirteen years later, in Tavita, the New Zealand Court of Appeal adopted a much more flexible approach. The appellant in Tavita faced deportation, but he had a child who would remain in New Zealand. He asked the Associate Minister of Immigration to exercise his statutory discretion under

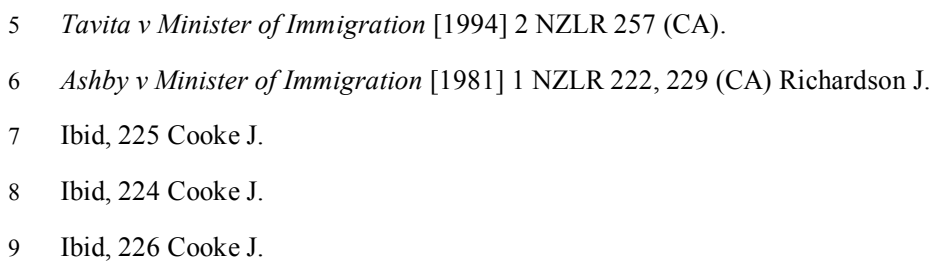


the Immigration Act 1987 to cancel the deportation order on humanitarian grounds. When the Minister refused his request, he appealed to the New Zealand courts. He argued that both the International Covenant on Civil and Political Rights (ICCPR) and the Convention on the Rights of the Child (CRC) required the Minister to make the best interests of the child a "primary consideration" in exercising its discretion under the statute. Relying on New Zealand's traditional dualist approach to treaties, the Minister responded that he was not obliged to take these treaty provisions into account because neither the ICCPR nor the CRC had been legislatively incorporated into domestic law. ${ }^{10}$

While the Court of Appeal did not rule directly on the treaty issue, ${ }^{11}$ its opinion did call into question the validity of the Minister's argument. The Court denounced the government's dualist position as "an unattractive argument, apparently implying that New Zealand's adherence to international instruments has been at least partly window dressing."12 The Court also appeared to repudiate its holding in Ashby, this time asserting that administrative decision-makers have an obligation to consider human rights treaty obligations regardless of the formal domestic legal status of the treaties in question. The Tavita court pointed to New Zealand's recent accession to the Optional Protocol to the ICCPR as support for its view. It explained: ${ }^{13}$

Since New Zealand's accession to the Optional Protocol, the United Nations Human Rights Committee is in a sense part of the country's judicial structure, in that individuals subject to New Zealand jurisdiction have direct rights of recourse to it. A failure to give practical effect to international instruments to which New Zealand is a party may attract criticism. Legitimate criticism could extend to the New Zealand Courts, if they were to accept the argument that, because a domestic statute giving discretionary powers in general terms does not mention international human rights norms or obligations, the Executive is necessarily free to ignore them.

The Court further emphasised "the duty of the judiciary to interpret and apply national constitutions, ordinary legislation and the common law in the light of the universality of human rights."14 Accordingly, it discussed international human rights treaty law, along with decisions of the European Court of Human Rights on deportation proceedings. ${ }^{15}$

10 Tavita, above n 5, 257 Cooke P.

11 The Court of Appeal adjourned the case in order to give the Minister - who had not known of the child's existence at the time of his ruling - an opportunity to reconsider the ruling. Ibid, 266 Cooke P.

12 Ibid, 259 Cooke P.

13 Ibid, 266 Cooke P.

14 Ibid.

15 Ibid, 262 and following Cooke $\mathrm{P}$. 
In adopting a rights-conscious approach to interpretation of immigration officials' statutory discretion, the Tavita court departed significantly from strict common law dualism. It refused to focus exclusively on the unincorporated status of the ICCPR within New Zealand domestic law, as the Government had urged it to do. Instead, the court looked outward, treating the Government's ratification of the Optional Protocol as evidence of New Zealand's strong commitment to the ICCPR treaty regime. The Tavita court thus shaped a more monistic, rights-conscious Charming Betsy canon - one that "places the courts ... in a position of oversight to avoid the possibility of international liability for the country as a whole."16

While the court's ruling in Tavita supports judicial review of administrative decisionmaking to ensure that administrators take into account international human rights obligations, the court left open a much more difficult issue: what weight should be given to international obligations in exercising such judicial review? As Claudia Geiringer has observed, it is not clear from the court's opinion whether administrative officials are required to conform their decisions to the requirements of international human rights law, or if it is sufficient that they take into account human rights obligations in their decision-making. Indeed, Geiringer has noted that the court's post-Tavita jurisprudence offers two conceptual models of the relevance of treaties to administrative power. First, the court has articulated a "mandatory consideration" model, in which administrative decisionmakers must take into account unincorporated treaties in exercising their statutory discretion. Second, the court has developed a much stronger "presumption of consistency" model, in which the courts will assume that the New Zealand Parliament intended to legislate consistently with its international treaty commitments - and administrative decision-makers must exercise their statutory authority accordingly. The Court of Appeal's post-Tavita jurisprudence has not clearly articulated the proper relationship between these two models. ${ }^{17}$

\section{B Canada}

In Baker $v$ Canada, ${ }^{18}$ the Canadian Supreme Court expanded on the New Zealand Court of Appeal's approach by addressing in more detail the weight that administrative decision-makers must give to unincorporated human rights treaties in exercising their statutory discretion. The facts of Baker are very similar to Tavita. Baker was an illegal immigrant who faced deportation to Jamaica, and she asked Canadian immigration authorities to exercise their discretion under Canada's Immigration Act 1985 to allow her to stay in Canada to care for her four Canadian-born children. They refused, and she appealed to the Canadian courts.

16 Steinhardt, above n 3, 1128.

17 Claudia Geiringer "Tavita and All That: Confronting the Confusion Surrounding Unincorporated Treaties and Administrative Law" (2004) 21 NZULR 67.

18 Baker v Canada [1999] 2 SCR 817. 
At issue in the case was the meaning of section 114(2) of Canada's Immigration Act, which permitted immigration authorities to exempt individuals from deportation for "compassionate or humanitarian considerations." Baker argued that provisions in the $\mathrm{CRC}$ required the immigration authority to make the best interests of her children "a primary consideration" in exercising its discretion under the statutory provision. ${ }^{19}$ The trial court certified the following question of statutory construction to the Court of Appeal: ${ }^{20}$

Given that the Immigration Act does not expressly incorporate the language of Canada's international

obligations with respect to the International Convention on the Rights of the Child, must federal

immigration authorities treat the best interests of the Canadian child as a primary consideration in

assessing an applicant under s. 114(2) of the Immigration Act?

The Court of Appeal answered the question in the negative, adopting a traditional dualist approach to Canada's version of the Charming Betsy canon. It acknowledged that "legislation should be interpreted, where possible, to avoid conflicts with Canada's international obligations";21 but it noted that the CRC had not been enacted into Canadian law and thus had no legal effect in Canada. The appeals court asserted that given the status of the Convention within domestic law, to interpret the statutory provision "to require that the discretion it provides for must be exercised in accordance with the Convention would interfere with the separation of powers between the executive and legislature."22

The Canadian Supreme Court reversed the decision, holding that immigration authorities must take into account the best interests of the child in exercising their statutory discretion. Justice Claire L'Heureux-Dubé, a strong proponent of transnational judicial dialogue on human rights, wrote the majority opinion. She adopted a rights-conscious, "contextual" approach to Canada's Charming Betsy canon that introduced monistic elements into the canon, while at the same time paying deference to its dualist roots. She first acknowledged that because the CRC had not been domestically implemented by the Canadian Parliament, "its provisions ... have no direct application within Canadian law."23 She thus rejected Baker's contention that administrators were required to comply with the literal terms of the CRC, which would have required them to make the best interests of the child "a primary consideration" in their decision.

19 Article 3 of the Convention on the Rights of the Child (20 November 1989) 1577 UNTS 3 provides, "In all actions concerning children, whether undertaken by public or private social welfare institutions, courts of law, administrative authorities or legislative bodies, the best interests of the child shall be a primary consideration."

20 Baker, above n 18, para 9 L'Heureux-Dubé.

21 Ibid, para 10 L'Heureux-Dubé.

22 Ibid.

23 Baker, above n 18, para 69 L'Heureux-Dubé. 
But in construing the meaning of the statutory provision in question, L'Heureux-Dubé $\mathrm{J}$ adopted a presumption of legislative intent that was (at a minimum) highly deferential to international human rights law: $:^{24}$

the legislature is presumed to respect the values and principles contained in international law, both customary and conventional. These constitute a part of the legal context in which legislation is enacted and read. In so far as possible, therefore, interpretations that reflect these values and principles are preferred.

As a result, she argued, "the values reflected in international human rights law may help inform the contextual approach to statutory interpretation and judicial review." 25 She cited the New Zealand Court of Appeal's decision in Tavita as support for this proposition. ${ }^{26}$

In applying this rights-conscious, "contextual" approach to statutory construction, L'HeureuxDubé J observed that the immigration authority had an obligation to exercise its statutory discretion "in accordance with the boundaries imposed [by] ... the principles of the rule of law, ...[and] the fundamental values of Canadian society." 27 And in discerning "fundamental Canadian values," she discussed at some length the principles of the Convention on the Rights of the Child. She pointed out that "[t]he values and principles of the $[\mathrm{CRC}]$ recognise the importance of being attentive to the rights and best interests of children when decisions are made that relate to and affect their future." 28

L'Heureux-Dubé J concluded that while immigration authorities need not make the best interests of the child a "primary" consideration (as the CRC requires), they "should consider children's best interests as an important factor, give them substantial weight, and be alert, alive and sensitive to them."29 She concluded that in cases where the immigration authority treated children's best interests "in a manner inconsistent with Canada's humanitarian and compassionate tradition . . . the [exercise of statutory discretion] will be unreasonable" ${ }^{130}$ and subject to reversal by the courts.

Not all members of the Canadian Supreme Court agreed with the majority's rights-conscious approach. Two judges categorically rejected the "contextual" approach to using unincorporated human rights treaties in statutory construction. They argued that it represented an inappropriate departure from the court's traditional dualist-oriented jurisprudence on the status of international law

\footnotetext{
24 Ibid, para 70 L'Heureux-Dubé

25 Ibid, para 70 L'Heureux-Dubé.

26 Ibid, para 70 L'Heureux-Dubé

27 Ibid, para 56 L'Heureux-Dubé

28 Ibid, para 71 L'Heureux-Dubé

29 Ibid, para 75 L'Heureux-Dubé.

30 Ibid
} 
within Canada's legal system. ${ }^{31}$ They warned of the dangers of developing a more monistic approach to statutory construction, arguing that "one should proceed with caution in deciding matters of this nature, lest we adversely affect the balance maintained by our Parliamentary tradition, or inadvertently grant the executive the power to bind citizens without the necessity of involving the legislative branch." 32 Moreover, the judges complained that the result of the court's rights-conscious approach would be that litigants are "able to achieve indirectly what cannot be achieved directly, namely, to give force and effect within the domestic legal system to international obligations undertaken by the executive alone that have yet to be subject to the democratic will of Parliament." 33 Indeed, the justices argued that unincorporated treaties have no relevance in statutory interpretation. In a clear statement of the traditional dualist position, they insisted that "the primacy accorded to the rights of children in the Convention . . . is irrelevant unless and until such provisions are the subject of legislation enacted by Parliament."34

\section{Australia}

While the Canadian Supreme Court's "contextual" approach to unincorporated human rights treaties represents a significant departure from traditional common law dualism, the High Court of Australia had taken the rights-conscious Charming Betsy canon even further. In a highly controversial decision, the Court held that an unincorporated treaty may give rise to a "legitimate expectation" that administrative decisionmakers will exercise their statutory discretion in conformity with the terms of the treaty. In Minister for Immigration and Ethnic Affairs $v$ Teoh, ${ }^{35}$ a Malaysian citizen faced deportation after having been convicted of a serious crime in Australia. He petitioned the Australian immigration authority for permanent resident status, arguing that his deportation would cause severe financial and emotional hardship for his Australian-born children. The immigration authority denied his petition, and he appealed to the Australian courts.

At issue on appeal was whether the immigration authority had properly exercised its discretion under the statutory provision pertaining to permanent resident permits. That provision instructed immigration officials to take into account a petitioner's family status and other "strong compassionate or other humanitarian grounds" in deciding whether to grant a permit. In reviewing Teoh's petition, the immigration authority had considered the hardships that his deportation would inflict on his children, but it had ruled that these considerations were outweighed by Teoh's criminal record. On appeal, Teoh argued that the immigration authority had given insufficient weight to

31 Ibid, para 79 Iacobucci and Corey JJ.

32 Ibid, para 80 Iacobucci and Corey JJ.

33 Ibid.

34 Ibid, para 81 Iacobucci and Corey JJ.

35 Minister for Ethnic and Immigration Affairs v Teoh (1995) 183 CLR 273 (HCA). 
family considerations. He asserted that the immigration authority was required under the terms of the CRC to make the best interests of Teoh's children "a primary consideration" in assessing his petition. (Australia has ratified the CRC, but it has not been legislatively incorporated into Australian law).

The Australian High Court agreed with Teoh's argument. Like the Canadian and New Zealand courts, it acknowledged traditional dualist limitations on unincorporated treaties, stating that such treaties do not vest individuals with enforceable rights under Australian law. ${ }^{36}$ But in the court's view, the absence of implementing legislation did not render the CRC irrelevant on the domestic legal plane. After all, the court emphasised: ${ }^{37}$

ratification by Australia of an international convention is not to be dismissed as a merely platitudinous

or ineffectual act, particularly when the instrument evidences internationally accepted standards to be

applied by courts and administrative authorities in dealing with basic human rights affecting the family

and children.

The Teoh court adopted a bold understanding of the meaning and consequences of the act of ratification: It asserted that ratification of a treaty "is a positive statement by the executive government of this country to the world and to the Australian people that the executive government and its agencies will act in accordance with the Convention." ${ }^{38}$ As such, ratification of a treaty alone served as "an adequate foundation for a legitimate expectation, absent statutory or executive indications to the contrary, that administrative decision-makers will act in conformity with" the treaty. ${ }^{39}$

Thus, according to the court, the Australian government's mere act of ratifying the CRC gave rise to legitimate expectations for individuals like Teoh that immigration officials would exercise their statutory discretion in conformity with the requirements of the treaty. Adopting such a rightsconscious approach, the Teoh court held that the immigration authority had an obligation to treat the best interests of children as "a primary consideration" in exercising its statutory discretion. ${ }^{40}$

The Australian High Court's decision in Teoh represents to date the most monistic judicial approach to the role of unincorporated human rights treaties in statutory interpretation. Indeed, the court's decision only makes sense from a monistic perspective. To a dualist, the decision is illogical: how can mere ratification of a treaty give rise to an expectation that domestic officials will

36 Ibid, 286-7 Mason CJ and Deane J.

37 Ibid, 291 Mason CJ and Deane J.

38 Ibid.

39 Ibid.

40 The court held that that the ratification of a treaty can give rise to "legitimate expectations" even in individuals who are unaware of the treaty's existence. Ibid. 
act in conformity with the treaty's obligations, when the treaty itself does not have the force of law on the domestic plane? As the dissenting judgment in Teoh pointed out: ${ }^{41}$

In international law, conventions are agreements between States . . The ratification of a treaty is not a

statement to the national community. It is, by its very nature, a statement to the international community. The people of Australia may note the commitments of Australia in international law, but, by ratifying the Convention, the Executive government does not give undertakings to its citizens or residents. . . How, when or where those undertakings will be given force in Australia is a matter for the federal Parliament. This is a basic consequence of the fact that conventions do not have the force of law within Australia.

From a monistic perspective, however, the Teoh court's approach to treaties is perfectly logical. The monist draws no distinction between "international" and "national" legal planes. To the monist, then, the act of ratification is not simply a promise to other sovereign nations: it is a "positive statement" to the entire international community, which necessarily encompasses the "national community" - the Australian people - as a subset of the larger whole. From this perspective, the Teoh court simply required administrative officials to fulfill the promise that the Australian government had already made to its citizens when it ratified the CRC: that it would conform its conduct to the terms of the treaty.

In Teoh, the Australian High Court (perhaps unwittingly) teed up a powerful struggle between traditional dualist-oriented policymakers and the monist-oriented members of the Court. Not surprisingly, then, the court's decision in Teoh was the subject of a considerable dualist backlash among policymakers in Australia. (Their response is similar in many respects to the current backlash in the United States Congress stemming from the United States Supreme Court's discussion of foreign and international law in Lawrence $v$ Texas $^{42}$ and Roper $v$ Simmons. ${ }^{43}$ ) Shortly after the court's decision, the Australian Attorney General and the Minister for Foreign Affairs issued a Joint Ministerial Statement, taking the position that mere ratification of a treaty should not be interpreted by the courts to give rise to an expectation that government officials would act in accordance with the treaty. ${ }^{44}$ The Joint Statement also explicitly reaffirmed the government's

41 Ibid, 316 McHugh J.

42 Lawrence v Texas (2003) 539 US 558.

43 Roper v Simmons (2005) 543 US 551.

44 See Gareth Evans, Minister for Foreign Affairs and Michael Lavarch, Attorney-General "International Treaties and the High Court Decision in Teoh" (10 May 1995) Press Release ("We state on behalf of the Government, that entering into an international treaty is not reason for raising any expectation that government decision-makers will act in accordance with the treaty if the relevant provisions of that treaty have not been enacted into domestic Australian law. It is not legitimate, for the purpose of applying Australian law, to expect that the provisions of a treaty not incorporated by legislation should be applied by decision-makers. Any expectation that may arise does not provide a ground for review of a decision."). 
commitment to traditional common law dualism. ${ }^{45}$ Moreover, members of the Australian Parliament have periodically introduced legislation that would overturn the court's ruling in Teoh. ${ }^{46}$ The decision has also been the subject of fierce academic debate in Australia. Its critics echo the concerns of some United States scholars that judicial approaches such as Teoh transform the traditional Charming Betsy canon into an effective "mandate for court-supervised incorporation of international law." 47

In more recent years, as the composition of the High Court has changed, proponents of the traditional dualist view have once again re-asserted their ascendancy in the Court, marking a significant retreat from Teoh. This trend has had a particular impact in the context discussed in this essay, namely in the impact of unincorporated human rights treaties, especially in the field of immigration. Thus, notably in Al-Kateb $v$ Godwin ${ }^{48}$ which I discuss further below, a majority of the Court held that Australia's international human rights obligations could not be read into the Australian Constitution so as to compel the Government to release from detention a stateless Palestinian who had been denied refugee status. The decision exposed a deep division of view between McHugh J, writing for the majority, and Gleeson CJ, Gummow and Kirby JJ. ${ }^{49}$ Nor has the polarisation within the High Court of Australia on this issue been confined to an isolated decision. On the contrary, there have been a succession of judgments in which the majority has expressly denied the relevance of international human rights norms, and comparative judicial decisions interpreting and applying them, with a minority taking the reverse view. ${ }^{50}$

45 Ibid. It stated, "we believe it is appropriate to retain the long-standing, widely accepted and well-understood distinction between treaty action undertaken by the Executive which creates international rights and obligations and the implementation of treaty obligations in Australian law. The implementation of treaties by legislation is the way that the rights, benefits and obligations set out in treaties to which Australia is a party are conferred or imposed on individuals in Australian law."

46 See Report of the Senate Legal and Constitutional Legislation Committee, Administrative Decisions (Effect of International Instruments) Bill 1997, tabled on 20 October 1997; Report of the Senate Legal and Constitutional Legislation Committee, Administrative Decisions (Effect of International Instruments) 1995, tabled on 28 September 1995. For a discussion of the legislative and government response, see Wendy Lacey "In the Wake of Teoh: Finding an Appropriate Government Response" [2001] Fed L Rev 9.

47 See Curtis A Bradley "Breard, Our Dualist Constitution, and the Internationalist Conception" (1999) 51 Stan L Rev 529, 547. Al-Kateb v Godwin [2004] HCA 37; (2004) 78 AJLR 1099; (2003) 208 ALR 124.

49 See also the extrajudicial comments of the Hon Michael Kirby "Deep Lying Rights - A Constitutional Conversation Continues" (2005) 3 NZJPIL 195, and the further authorities discussed in Part II below.

50 See, for example, Attorney-General (WA) v Marquet (2003) 217 CLR 545 (electoral rights); Shaw v Minister for Immigration and Multicultural Affairs (2003) 218 CLR 28 (expulsion of aliens); Behrooz v Secretary of the Department of Immigration, Multicultural and Indigenous Affairs (2004) 78 ALJR 1056 (detention conditions for migration detainee); Re Colonel Aird; Ex parte Albert (2004) 78 ALJR 1451 (jurisdiction of military tribunals). The High Court also found unanimously that the clear terms of the Migration Act 1958 (Cth) precluded any argument as to the application of the Convention on the Rights of 


\section{United States}

Although no United States court to date has adopted a rights-conscious construction of the Charming Betsy canon similar to those of the Tavita, Baker, and Teoh courts, plaintiffs in United States courts are beginning to cite these foreign decisions in advocating the adoption of a similar approach. The United States Court of Appeals for the Ninth Circuit recently confronted this issue in an immigration case very similar on its facts to Tavita, Baker, and Teoh. In Cabrera-Alvarez v Gonzalez, ${ }^{51}$ the petitioner, a Mexican citizen, sought a cancellation of removal order to prevent economic and emotional hardship to his two children, both of whom were United States citizens. The statute in question permitted cancellation of removal to aliens who could show "exceptional and extremely unusual hardship" to family members. Cabrera-Alvarez argued that the immigration judge had interpreted this statutory language in a manner inconsistent with international law, and thus in violation of the Charming Betsy canon of statutory construction. Like the petitioners in Tavita, Baker, and Teoh, Cabrera-Alvarez pointed to provisions in the CRC requiring administrative officials to make the best interests of the child "a primary consideration" in their decision making. (Unlike Australia, Canada and New Zealand, the United States is not a party to the CRC. It has signed, but has not ratified, the CRC.)

The Ninth Circuit began its discussion by stating the Charming Betsy canon as a "presumption that Congress intends to legislate in a manner consistent with international law." 52 It then acknowledged that because the United States has not ratified the CRC, it is not "the supreme Law of the Land" under the United States Constitution. ${ }^{53}$ Nevertheless, the court suggested that it could take into account whether the immigration statute complied with the terms of the CRC, "assuming ... that the Convention has attained the status of 'customary international law."'54 The court then assumed for purposes of Cabrera-Alvarez's appeal that the CRC had attained the status of customary international law, and that Congress intended to legislate in a manner consistent with the treaty.

Proceeding on these assumptions, the Ninth Circuit discussed at some length various provisions of the CRC, as well as the Australian and Canadian courts' decisions in Baker and Teoh. ${ }^{55}$ It held that the immigration judge had in effect made the best interests of Cabrera-Alvarez's children "a primary consideration" in applying the statutory "exceptional and extremely unusual hardship"

the Child in determining the rights of migrant children held in detention: Minister for Immigration, Multicultural and Indigenous Affairs v B (2004) 78 ALJR 737. 
standard. ${ }^{56}$ Accordingly, it held that the immigration judge's decision was consistent with the CRC, "even assuming that the Convention is 'customary international law' and that its dictates are relevant to a proceeding involving deportation of a parent." 57 Although the Ninth Circuit ruled against Cabrera-Alvarez, its analysis suggests a willingness to consider the adoption of a rights-conscious Charming Betsy canon in an appropriate case.

\section{E "Rights-Conscious" Statutory Interpretation: Observations}

A striking feature of the emerging rights-conscious approach to statutory interpretation is that it is both a product of, and serves to further promote, transnational judicial dialogue on human rights. The New Zealand court's landmark decision in Tavita, for example, greatly influenced the Australian, Canadian, and United States courts' decisions in Teoh, Baker, and Cabrera-Alvarez. Indeed, the Australian and Canadian courts not only relied upon Tavita as precedent; they further developed and even expanded Tavita's rights-conscious approach to statutory interpretation. Other common law courts have also cited Tavita as precedent for utilising unincorporated human rights treaties. ${ }^{58}$

Another interesting feature of the rights-conscious Charming Betsy canon is its departure from strict common law dualism. Courts employing the rights-conscious approach do not tend to focus on the domestic legal status of the human rights treaties in question: they do not seem overly concerned with the unincorporated status of the treaties, for example, nor do they utilise the treaties as evidence of customary international law (with the exception of Cabrera-Alvarez). Instead, the courts view the act of treaty ratification itself as evidence of their countries' strong normative commitments to the international human rights legal regime. And they insist that these normative commitments cannot stop at the country's borders: instead, domestic statutes must be read consistently with (or at least take into account in some fashion) international human rights law whether or not the dualist-oriented political branches intended the act of ratification to produce such an effect.

\section{THE CONSTITUTIONAL CHARMING BETSY CANON}

By far the most ambitious use of the Charming Betsy canon to date is the development of a "constitutional Charming Betsy canon" to construe domestic constitutional provisions in conformity with international human rights law. The most vocal judicial proponent of a constitutional Charming Betsy canon is Justice Michael Kirby of the Australian High Court. He asserts that "where the Constitution is ambiguous, [a court] should adopt that meaning which conforms to the

\footnotetext{
56 Ibid.

57 Ibid, 1011 Circuit Judge Graber.

58 See for example, Thomas $v$ Baptiste [2000] 2 AC 1 (PC Trinidad)
} 
principles of universal and fundamental rights rather than an interpretation that would involve a departure from such rights. ${ }^{159}$

Kirby $\mathrm{J}$ has applied the constitutional Charming Betsy canon in concurring opinions in a variety of cases before the Australian High Court. He has used it in a case involving constitutional powers regarding aboriginal peoples, ${ }^{60}$ in a case addressing the Australian Constitution's version of the United States takings clause, ${ }^{61}$ and, most recently, in a case addressing the government's power to indefinitely detain stateless persons. ${ }^{62}$ He has also advocated adoption of the canon in his frequent lectures at international judicial conferences (and at the Annual Meeting of the American Society of International Law). ${ }^{63}$

In employing the constitutional Charming Betsy canon, Kirby $\mathrm{J}$ is quick to acknowledge traditional dualist limitations on international law. He notes that a court should not "adopt an interpretative principle as a means of introducing, by the backdoor, provisions of international treaties or other international law concerning fundamental rights not yet incorporated into Australian domestic law."64 Nevertheless, he asserts that "to the full extent that its text permits, Australia's Constitution, as the fundamental law of government in this country, accommodates itself to international law."65

An intriguing aspect of Kirby's J position is the precedent that he cites in support of his constitutional Charming Betsy canon. He relies heavily on other common law courts' far less radical uses of international human rights law to inform constitutional interpretation. For example, he cites as support the United States Supreme Court's (by comparison) extremely modest use of foreign and international law in interpreting the United States Constitution. Indeed, he makes the astonishing assertion that the United States Supreme Court's very brief discussions of foreign or international sources in Atkins $v$ Virginia and Lawrence $v$ Texas is evidence that "the majority view in the United States now appears to favour the [constitutional Charming Betsy] interpretive principle." 66

59 Kartinyeri $v$ Commonwealth [1998] HCA 22, para 166 Kirby J.

60 Ibid, para 53 Brennan CJ and McHugh J.

61 Newcrest Mining v Commonwealth (1997) 190 CLR 513; (1997) 71 ALJR 1346, 1423-26 (HCA) Kirby J.

62 Al Kateb v Commonwealth [2004] HCA 37.

63 See for example, Michael Kirby "International Law: The Impact on National Constitutions" (Address to American Society of International Law, 30 March 2005).

Newcrest Mining, above n 61, 657.

65 Ibid.

Al Kateb, above n 62, 188. Justice Kirby would no doubt have relied instead on the United States Supreme Court's much more extensive use of international law in Roper $v$ Simmons, if that ruling had been available at the time of the Al Kateb decision. 
Most importantly for the purposes of this essay, Kirby $\mathrm{J}$ argues that the novel (and deeply monistic) constitutional Charming Betsy canon is simply a logical extension of the long-standing traditional Charming Betsy canon for statutory construction. He argues: ${ }^{67}$

every other statute of this land is read, in the case of ambiguity, to avoid so far as possible [conflicts

with international law].... Likewise, the Australian Constitution, which is a special statute, does not

operate in a vacuum. It speaks to the people of Australia. But it also speaks to the international

community as the basic law of the Australian nation which is a member of that community.

Kirby J's advocacy of a constitutional Charming Betsy canon is thus rooted in his conception of the domestic constitution not as a foundational text, but as a special kind of statute or "basic law". Moreover, in his conception, a constitution no longer speaks exclusively - or even primarily - to the national community that gave it birth; it now speaks to the broader international community of which the national community is a part. ${ }^{68}$ Kirby $\mathrm{J}$ thus appears to adopt a strongly monistic view of the role of the domestic constitution. For the monist, there is no clear distinction between "international" and "national" law: accordingly, the domestic constitution must be a kind of statement that "speaks" to both international and national audiences, and is likewise informed by the views of both audiences.

Kirby's J position demonstrates the dramatic potential of the rights-conscious Charming Betsy canon when it is applied to constitutional, rather than statutory, interpretation. If Justice Kirby and other advocates of the canon are serious in their contention that courts should interpret ambiguities in domestic constitutional provisions "consistently with" international human rights law, the canon has the potential to work a fundamental reordering in the traditional common law conception of the relationship between domestic and international law. After all, "ambiguities," broadly defined, are legion in the constitutions of most common law countries: as foundational texts, constitutions set out basic rights and values with little specific guidance as to the drafters' intent with respect to their application. Constitutions are, in a sense, inherently ambiguous. Thus judges who wish to interpret their constitutions consistently with international human rights law will not have to look far to find an appropriate "ambiguity" in the text that needs to be addressed.

67 Kartinyeri, above n 59, 418

68 See also Newcrest Mining, above n 61, 658 ("the Constitution not only speaks to the people of Australia who made it and accept it for their governance. It also speaks to the international community as the basic law of the Australian nation which is a member of that community."). In this sense, Justice Kirby's approach echoes the Teoh court's approach to the ratification of a treaty, which, in the court's view, amounted to a "positive statement" to both the international and national communities. 
As a structural matter, the rights-conscious Charming Betsy canon may prove to be highly problematic when applied to constitutional interpretation. In this regard, McHugh $\mathrm{J}$ of the Australian High Court (one of Justice Kirby's sharpest critics) argues: ${ }^{69}$

The rationale for the [traditional] rule [that statutes should be construed to conform with the rules of international law] . . . is inapplicable to a Constitution - which is a source of, not an exercise of, legislative power. The rule, where applicable, operates as a statutory implication. But the legislature is not bound by the implication. It may legislate in disregard of it. If the rule were applicable to a Constitution, it would operate as a restraint on the grants of power conferred. The Parliament would not be able to legislate in disregard of the implication.

In other words, a strict interpretation of the constitutional Charming Betsy canon would involve a presumption that a constitution's drafters intended to comply with international law. It is difficult to see how either the executive or the legislative branch would be able to act to overcome such a constitutional (as opposed to statutory) presumption.

A constitutional Charming Betsy canon, if thus broadly defined and strictly applied, could effectively result in the subordination of all domestic law to international treaty law. The rightsconscious Charming Betsy canon as applied to statutory interpretation certainly erodes traditional common law dualism to some degree. But the broad adoption of a constitutional Charming Betsy canon would result in the final triumph of monism - and the repudiation of dualism - in the common law legal tradition.

\section{CONCLUSION}

Over a decade ago, Professor Ralph Steinhardt made a prediction that "as the international legal system addresses more substantive aspects of economic and political life . . the Charming Betsy principle should take on a heightened practical and theoretical significance."70 That prediction has been borne out in the human rights context, as courts throughout the common law world begin to make use of the Charming Betsy canon to ensure that domestic legal texts are read consistently with their countries' international human rights commitments. By developing a rights-conscious approach to the Charming Betsy canon, these courts are expanding the traditional canon to accommodate a world in which jurisdictional boundaries between "domestic" and "international" legal regimes are increasingly blurred. Moreover, in employing a rights-conscious approach, they are significantly eroding the common law legal tradition's historical commitment to dualism.

The goals of this short essay have been modest: to chronicle the development of the rightsconscious approach in one particular statutory context (judicial review of administrative decisionmaking in immigration law), to suggest where the rights-conscious approach might next

69 Al Kateb, above n 62, para 66 McHugh J.

70 Steinhardt, above n 3, 1197. 
take the courts (a constitutional Charming Betsy canon), and to highlight the role of transnational judicial dialogue in the emergence of the trend. But the rights-conscious Charming Betsy canon is clearly in its infancy. Much scholarly work remains to be done to assist the courts in developing a rigorous rights-conscious Charming Betsy canon that will address the myriad normative legitimacy issues that arise. $^{71}$

71 While these normative legitimacy issues are well beyond the scope of this essay, I address them at length in another article. See Melissa A Waters "Creeping Monism: The Judicial Trend Toward Interpretive Incorporation of Human Rights Treaties" (2007) 107 Colum L Rev 628. 
